\title{
Cytotoxic activity induced by crude extracts of Ganoderma lucidum (W. Curt.: Fr.) P. Karst. on mouse myeloma cancer cell-line.
}

\begin{abstract}
Ganoderma lucidum powder using hot water and methanol extraction methods indicated a twofold more active cytotoxic activity with IC50 of $44 \pm 3.8 \mu \mathrm{g} / \mathrm{ml}$ in the latter method. The representative dose-response curves of the G. lucidum crude extracts on J558 cell-lines revealed that there were great similarities between the curves which reflected rapid killing activities. The percentage viability of the J558 cell exposed to these crude extracts was dose dependent only up to $150 \mu \mathrm{g} / \mathrm{ml}$. After which, there was no significant reduction when the dose was increased to 200 or $400 \mu \mathrm{g} / \mathrm{ml}$. The morphological alterations induced by the crude extract were examined under the phase contrast, fluorescent and electron microscopy. When J558 cells were treated with doses higher than $50 \mu \mathrm{g} / \mathrm{ml}$ of the crude extract, obvious morphological changes and apoptosis occurred after $72 \mathrm{~h}$. At $400 \mu \mathrm{g} / \mathrm{ml}$, most of the cells showed necrosis characterized as small fragments with uniformly stained red nuclei. The apoptotic and necrotic cells increased by 16.5 and $29.1 \%$, respectively whereas the viable cells decreased by as much as 45.6. The mode of cell death via apoptosis was $3.6 \%$ higher than necrosis. However, these morphological changes were not observed in the case of 3T3 cells. Results obtained from scanning electron microscopy and transmission electron microscopy further confirmed the occurrence of various apoptotic and necrotic features.
\end{abstract}

Keyword: Ganoderma lucidum; IC50; J558; Necrosis; Apoptosis. 